Актуальні проблеми розвитку економіки регіону. Вип 17. T.2

8. On approval of the Strategy for the development of tourism and resorts for the period up to 2026. Cabinet Ministry of Ukraine, www.kmu.gov.ua/npas/249826501. Accessed 20 Oct. 2021.

9. "The EBRD has updated the Roadmap to support the tourism business in Ukraine. Ukrinform, www.ukrinform.ua/rubric-tourism/3227791-ebrr-onoviv-doroznu-kartu-pidtrimki-turisticnogo-biznesu-vukraini.html. Accessed 20 Oct. 2021.

УДК 338.48-049.5]:616-036.21:578.834"2019"

doi: 10.15330/apred.2.17.178-189

\title{
БЕЗПЕКОВІ АСПЕКТИ РОЗВИТКУ ТУРИЗМУ В УМОВАХ ПАНДЕМЇ̈ COVID-19
}

Уманський державний педагогічний університет імені Павла Тичини, Міністерство освіти і науки України, кафедра технологій та організації туризму і готельно-ресторанної справи, вул. Садова, 2, м. Умань, 20300, Україна,

${ }^{1}$ тел.: +380974872048, e-mail: irina_kurul@ukr.net, ORCID: 0000-0001-9814-195X

2 тел.: +380976188989, e-mail: luda_um@ukr.net, ORCID: 0000-0003-2788-6991

Анотація. Мета статті полягає в обгрунтуванні особливостей, проблем та механізмів забезпечення безпеки туризму в умовах пандемії COVID-19.

Під час дослідження були використані діалектичний та абстрактно-логічний методи, методи системного підходу, порівняння, спостереження, аналізу, синтезу, індукції, дедукції та ін.

Інформаційною базою дослідження є вітчизняні та міжнародні нормативно-правові акти, інформація Всесвітньої туристичної організації, Міністерства культури і туризму Турецької Республіки, наукові публікації, інтернет-джерела.

Визначено сукупність обставин, що вказують на необхідність вирішення проблем забезпечення достатнього рівня безпеки для розвитку туризму в умовах пандемії COVID-19. Проаналізовано сучасний стан галузі та виявлено тенденції, які впливають на розвиток туризму в періоди встановлення карантину або обмежувальних заходів, пов'язаних із поширенням коронавірусної хвороби. Охарактеризовано проблеми забезпечення безпеки в туризмі, що стримують розвиток туристичної галузі. Обгрунтовано, що особливості функціонування туристичної галузі в умовах пандемії COVID-19 значною мірою залежать від скоординованих дій урядів країн щодо безпечності поїздок, узгодження протоколів безпеки та ефективних комунікацій, у контексті яких реалізуються заходи державної політики забезпечення безпеки розвитку туризму. Визначено чинники, що дозволяють стимулювати зростання рівня безпеки сфери туризму. Доведено, що необхідність забезпечення превентивних заходів із запобігання ризиків у сфері туризму $є$ важливим завданням як кожної окремої країни, так і міжнародних організацій. Проаналізовано заходи, інструкції та методи захисту туристів, які були визначені міжнародними організаціями як необхідні. Розглянуто заходи, які впроваджуються країнами світу для мінімізації негативних наслідків кризи в туристичній галузі та забезпечення іï 
подальшого функціонування й пристосування до обмежувальних економічних умов розвитку. Окреслено напрями забезпечення безпеки учасників туристичного ринку для відновлення їх туристичної активності.

Наукова новизна полягає в оцінці загроз розвитку туризму та виявленні стійких тенденцій змін, як наслідку їх прямого впливу, в умовах пандемії COVID-19 та обгрунтуванні необхідності стимулювання розробки заходів безпеки в туристичній галузі з урахуванням наявного практичного досвіду країн світу.

Практичне значення одержаних результатів полягає в можливості використання теоретичних висновків і практичних рекомендацій для подальшого розвитку туризму в обмежувальних умовах, що пов'язані з поширенням коронавірусної хвороби.

Ключові слова: туризм, міжнародний туризм, суб'єкти туристичної діяльності, туристичний ризик, безпека в туризмі, загрози безпеці, економічна безпека туристичної галузі.

\title{
Kyryliuk I. M. ${ }^{1}$, Chvertko L. A. ${ }^{2}$ SAFE ASPECTS OF TOURISM DEVELOPMENT IN THE CONVENTION OF THE COVID-19 PANDEMIC
}

\author{
Pavlo Tychyna Uman State Pedagogical University, \\ Ministry of Education and Science of Ukraine, \\ Department Technologies and Organization of Tourism and \\ Hotel and Restaurant Business; \\ Sadova str., 2, Uman, \\ 20300, Ukraine,

\begin{abstract}
The purpose of the article is to substantiate the features, problems and mechanisms to ensure the safety of tourism in a pandemic COVID-19.

During the study, dialectical and abstract-logical methods, methods of a systematic approach, comparison, observation, analysis, synthesis, induction, deduction, etc. were used.

The information base of the study is domestic and international regulations, information from the United Nations World Tourism Organization, the Ministry of Culture and Tourism of the Republic of Turkey, scientific publications, Internet sources.

A set of circumstances has been identified that indicate the need to address the issues of ensuring a sufficient level of security for tourism development in the context of the COVID-19 pandemic. The current state of the industry is analyzed and trends that affect the development of tourism during periods of quarantine or restrictive measures related to the spread of coronavirus disease are identified. The factors that allow to stimulate the growth of the level of security of tourism development are identified. The problems of security in tourism that hinder the tourism industry development are described. It is substantiated that the peculiarities of the functioning of the tourism industry in the context of the COVID-19 pandemic largely depend on the coordinated actions of governments on travel security, harmonization of safety protocols and effective communications, in the context of which state policy measures are implemented. It is proved that the need to provide preventive measures to prevent risks in the field of tourism is an important task of each individual country and international organizations. Measures, instructions and methods of tourist protection, which were identified by international organizations as necessary, are analyzed. The measures implemented by the countries of the world to minimize the negative consequences of the crisis in the tourism industry and ensure its further functioning and adaptation to the restrictive economic
\end{abstract}


Актуальні проблеми розвитку економіки регіону. Вип 17. T.2

conditions of development are considered. The directions of ensuring the safety of the participants of the tourist market for the restoration of their tourist activity are outlined. The scientific novelty is to assess the threats to tourism and identify sustainable trends as a consequence of their direct impact in the context of the COVID-19 pandemic and justify the need to stimulate the development of security measures in the tourism industry based on current practical experience. The practical significance of the obtained results consists in the possibility of using theoretical conclusions and practical recommendations for the further development of tourism in the restrictive conditions associated with the spread of coronavirus disease.

Keywords: tourism, international tourism, subjects of tourism activities, tourism risk, tourism security, security threats, economic security of the tourism industry.

Вступ. Розвиток туристичної галузі відбувається в нестабільному середовищі, яке створює загрози та небезпеки для іï ефективного функціонування. Одним з основних чинників впливу на сучасні економічні процеси та безпеку туристичного бізнесу $є$ пандемія COVID-19. Через поширення пандемію коронавірусу туристична галузь опинилася в кризовій ситуації, негативні наслідки якої здійснюють руйнівний вплив на економіку та зайнятість у світі.

Оцінка впливу пандемії COVID-19 на міжнародний туризм у 2020 та 2021 роках свідчить про значне зниження кількості міжнародних туристів як на регіональному, так і глобальному рівнях (рис. 1-2).

\section{World}

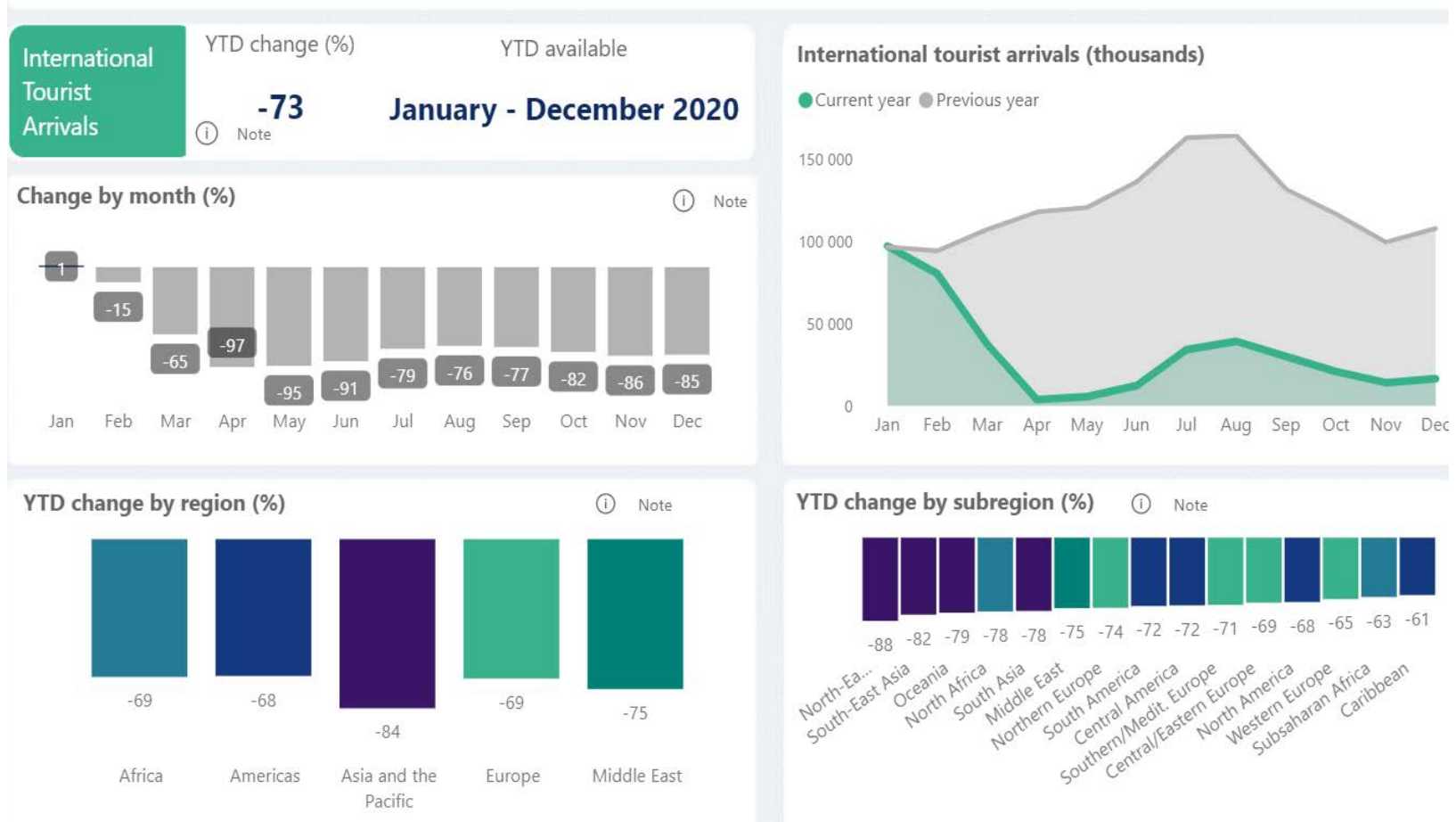

Puc. 1. Вплив пандемії COVID-19 на міжнародний туризм у 2020 році*

Fig.1. The impact of the COVID-19 pandemic on international tourism in 2020

*Джерело: [1]. 


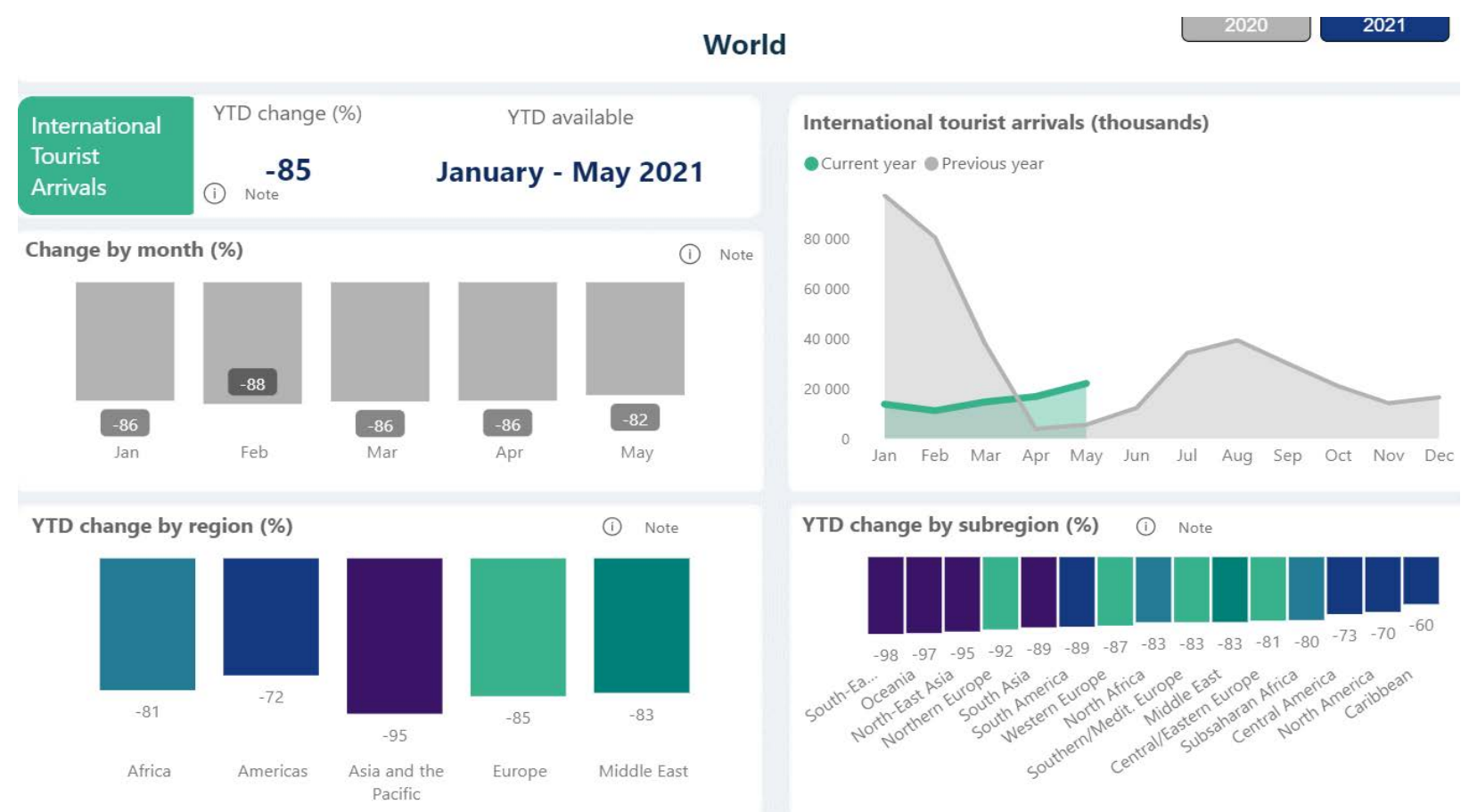

Puc. 2. Вплив пандемії COVID-19 на міжнародний туризм у 2021 році*

Fig.2. Impact of the COVID-19 pandemic on international tourism in 2021 *Джерело: [2].

За даними «World Tourism Barometer» Всесвітньої туристичної організації (BTO) карантинні заходи, які були введені у зв'язку із поширенням пандемії COVID-19, призвели до зниження кількості міжнародних туристичних прибуттів у січні-травні 2021 р. на 85\% у порівнянні з аналогічним періодом 2019 р. та на 65\% у 2020 р. При цьому в Азіатсько-Тихоокеанському регіоні, який в першу чергу постраждав від пандемії COVID-19, кількість прибуттів міжнародних туристів у січні-травні 2021 р. знизилась на 95\%, на Близькому Сході - на 83\%, в Америці даний показник зменшився на $72 \%$ та Африці - на $81 \%$ [2].

Однак, починаючи з травня 2021 р., намітилася слабка тенденція до зростання міжнародного туризму завдяки поступовому зняттю обмежень на поїздки в окремих країнах, відновленню міжнародних рейсів i перезапуску деяких внутрішніх i внутрішньорегіональних ринків.

Подальше відновлення туризму залежить від скоординованих дій урядів країн щодо безпечності поїздок, узгодження протоколів безпеки та ефективних комунікацій, які зможуть відновити довіру споживачів туристичних послуг.

Проблемам забезпечення безпеки туризму присвячені наукові доробки багатьох відомих вчених, серед яких Голод А. П. [3], Бобкова А. Г., Кудреватих С. О. та Писаревський Є. Л. [5], Захаров О. І. та Снігир А. В. [6], Забаштанський М. М., Забаштанська Т. В. та Роговий А. В. [7], Лазарева А. П. [9] та ін. Проте нині питання забезпечення відповідного рівня економічної безпеки держав у цілому й безпеки функціонування та розвитку туризму набуло особливої актуальності й потребує подальшого дослідження.

Постановка завдання. Мета статті полягає в обгрунтуванні особливостей, проблем та механізмів забезпечення безпеки туризму в умовах пандемії COVID-19.

Під час дослідження були використані діалектичний та абстрактно-логічний методи, методи системного підходу, порівняння, спостереження, аналізу, синтезу, індукції, дедукції та ін. 
Результати. Ключовим напрямом модернізації туристичної сфери на сучасному етапі є гарантування безпеки туризму, що характеризується відсутністю загроз і дає можливість забезпечити стабільний розвиток у майбутньому [3, с. 32].

Загрози економічної безпеки певної галузі, з точки зору О. Денисова, можна визначити як сукупність умов подій та факторів, які створюють небезпеку для реалізації економічних інтересів підприємств цієї галузі [4, с. 12].

Безпека туризму, на думку вчених, це динамічний стан захищеності сфери туризму від внутрішніх і зовнішніх загроз, що дає змогу забезпечити іiі надійне існування і стійкий розвиток [5, с. 7].

У туристичній сфері загрози безпеці суб'єктів туристичної діяльності визначають як поняття, що характеризує дію, процес або явище, в результаті яких виникає можливість зниження конкурентоспроможності туристичного продукту, що призводить до зменшення попиту на нього, недоотримання очікуваної величини прибутку або зазнання збитків підприємством [6, с. 302].

Сучасні дослідники, зокрема, М. Забаштанський, Т. Забаштанська та А. Роговий пропонують розглядати категорію «економічна безпека туристичної галузі» як такий стан туристичної галузі, за якого забезпечується можливість іiі результативного функціонування з урахуванням внутрішніх і зовнішніх загроз, спроможність повного та безперебійного задоволення туристичного попиту вітчизняних та іноземних туристів для забезпечення стійкого збалансованого розвитку національної економіки [7, с. 52].

Визначення безпеки в галузі туризму як сукупності факторів, що характеризують соціальний, економічний, правовий та інший стан забезпечення прав і законних інтересів громадян, юридичних осіб та держави в галузі туризму, знайшло своє відображення в Законі України «Про туризм» [8].

Складові економічної безпеки в туризмі, які виокремлюються відповідно до об'єктів безпеки туристичної сфери, представлені на рис. 3.

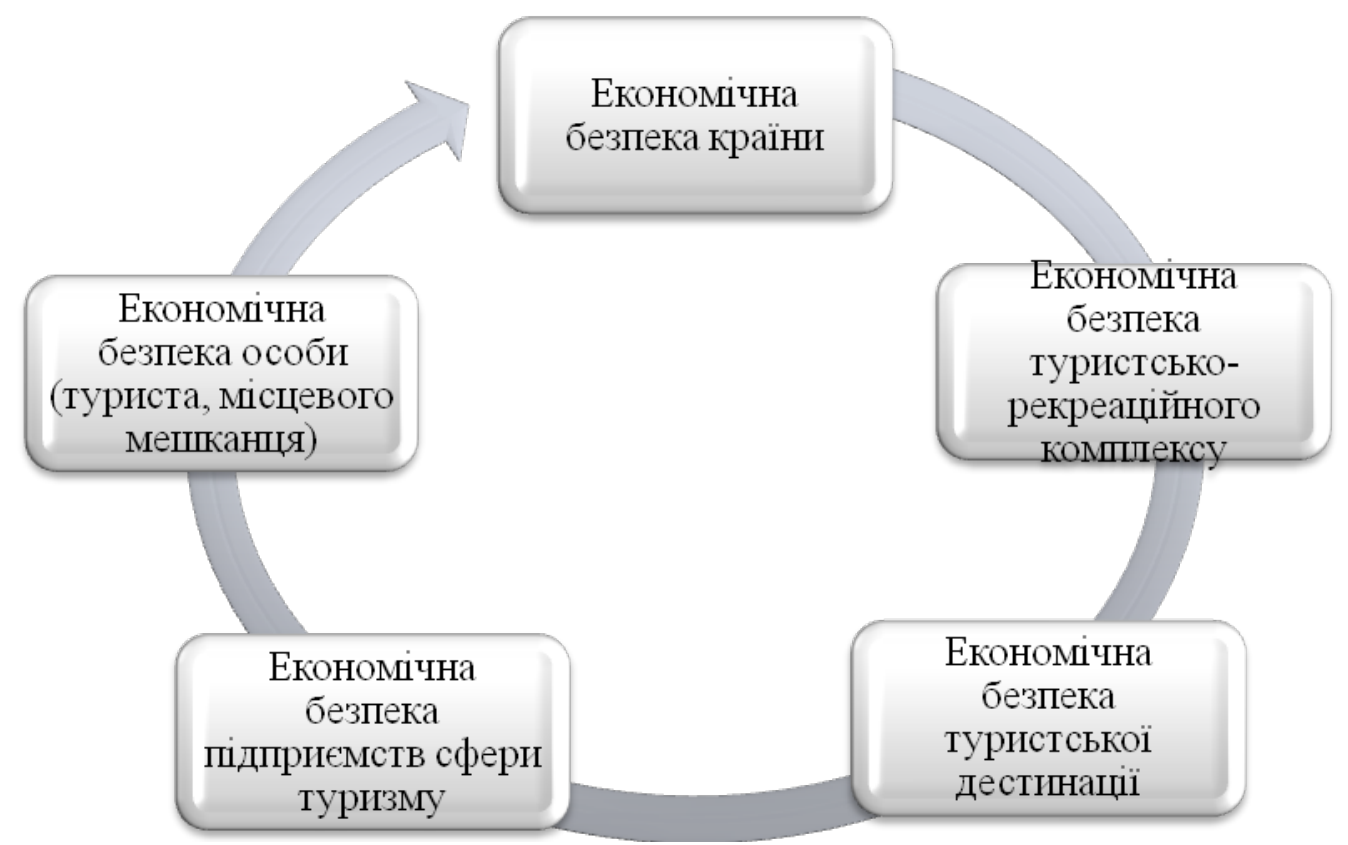

Puc. 3. Складові економічної безпеки в туризмі відповідно до об'єктів безпеки туристичної сфери*

Fig. 3. Components of economic security in tourism in accordance with the objects of security in the tourism sector

*Джерело: розроблено авторами за даними [9, с. 272]. 
Ефективна економічна безпека індустрії туризму можлива лише за умови забезпечення комплексного і системного підходу до іiї організації. Ефективне державне управління у сфері туризму покликане забезпечувати економічну безпеку шляхом створення відповідної нормативно-правової бази, яка б гарантувала високий ступінь безпеки туризму, життя і здоров'я всіх учасників туристичної діяльності.

Забезпечення превентивних заходів із запобігання ризиків у сфері туризму $\epsilon$ важливим завданням як кожної окремої країни, так i міжнародних організацій. Розробку відповідних інструкцій та чітке визначення заходів безпеки для учасників туристичного ринку покладено на Всесвітню туристичну організацію, рекомендації якої $є$ як основним комплексом дій, так i основою для формування місцевих, регіональних та/або національних додаткових комплексів дій.

Всесвітньою туристичною організацією для підтримки туристичної галузі в умовах пандемії COVID-19 сформовано «Глобальний кризовий комітет 3 туризму». Мета створення такого органу полягає в: максимальному сприянні урядам країн світу здійснення комплексу заходів із підтримки функціонування туристичної сфери; розробці та реалізації планів відновлення світової туристичної індустрії; підготовці Пакету технічної допомоги для відновлення туризму. До складу Комітету входять представники держав-членів й афілійованих членів ВТО, а також Всесвітньої організації охорони здоров'я, Міжнародної організації цивільної авіації та Міжнародної морської організації. Для забезпечення скоординованого та ефективного реагування приватний сектор представлений Міжнародною радою аеропортів, Міжнародною асоціацією круїзних ліній, Міжнародною асоціацією повітряного транспорту i Всесвітньою радою з подорожей і туризму. Укладення та ратифікація міждержавних домовленостей сприяє мінімізації негативних наслідків пандемії COVID-19 й відновленню довіри туристів до безпечних подорожей.

Важливим критерієм відновлення туристичної сфери повинно бути досягнення оптимального балансу між питаннями безпеки, охорони здоров'я та економічними інтересами. Для пом'якшення наслідків коронакризи в сфері туризму і відновлення туристичної діяльності Всесвітньою туристичною організацією розроблено ряд рекомендацій, в яких передбачені заходи «термінової і рішучої підтримки», що спрямовані на допомогу світовому туристичному сектору не тільки оговтатися від безпрецедентної проблеми COVID-19, а й забезпечити йому подальше зростання [10]. Зазначені рекомендації являють собою комплексний перелік заходів для органів влади та суб’єктів приватного сектора, що розділені на три ключові напрями:

1. Управління кризою і пом'якшення іiї наслідків: рекомендації, що стосуються збереження робочих місць; підтримки самозайнятих працівників; забезпечення ліквідності; сприяння розвитку навичок і перегляду податків, зборів та правил, що стосуються подорожей і туризму;

2. Забезпечення стимулів розвитку і прискорення відновлення туристичної галузі: підкреслюється важливість надання фінансових стимулів, у т. ч. сприятливої податкової політики; зняття обмежень на поїздки, як тільки це дозволить ситуація у сфері охорони здоров'я; сприяння спрощенню візового режиму; підвищення ролі маркетингу й рівня довіри споживачів туристичних послуг;

3. Підготовка до майбутнього: беручи до уваги унікальну здатність туризму сприяти економічному зростанню як на місцевому, так і національному рівнях, рекомендується приділяти більше уваги внеску сектора в «Порядок денний сталого розвитку до 2030 року» та формувати стійкість цього сектора, враховуючи уроки сучасної кризи. Рекомендації закликають уряди та суб'єктів приватного сектору 
Актуальні проблеми розвитку економіки регіону. Вип 17. T.2

розробляти плани готовності до викликів майбутнього та використовувати цю можливість для переходу до циркулярної економіки.

Оскільки все більша кількість країн пом'якшує обмеження на поїздки Всесвітньою туристичною організацією створено новий інструмент відновлення глобального туризму «Tourism Recovery Tracker». Цей інструмент $є$ результатом партнерства міжнародних організацій та приватного сектору. Зазначена інформаційна панель містить щомісячні ключові показники ефективності туризму за регіонами та субрегіонами (міжнародні туристичні прибуття, кількість місць на міжнародних і внутрішніх авіарейсах, бронювання авіаперельотів, пошук та бронювання готелів, рівень їх заповненості та попит на короткострокову оренду, настрої подорожуючих, інформація про COVID-19 за 14 днів на 100 тис. осіб). Tourism Recovery Tracker дає змогу порівняти відновлення сектору в реальному часі як на глобальному, так i регіональному рівнях [11].

Зі свого боку уряд кожної країни запроваджує заходи для мінімізації негативних наслідків кризи в туристичній галузі та для забезпечення ії подальшого функціонування й пристосування до обмежувальних економічних умов розвитку (табл. 1). Наразі існує два загальних підходи до подолання кризи:

- забезпечення доступних кредитних ліній для представників бізнесу;

- відтермінування сплати боргових і податкових зобов'язань для суб'єктів підприємництва [12, с. 11].

Табличя 1

Урядові заходи, які застосовуються країнами для подолання кризи в туристичній галузі в умовах пандемії COVID-19*

Table 1

Government measures are taken by countries to overcome the crisis in the tourism industry in the context of the COVID-19 pandemic

\begin{tabular}{|c|c|c|}
\hline Країна & $\begin{array}{c}\text { Забезпечення доступних кредитних } \\
\text { ліній для представників бізнесу }\end{array}$ & $\begin{array}{c}\text { Відтермінування сплати боргових } \\
\text { і податкових зобов'язань для } \\
\text { суб’єктів підприємництва }\end{array}$ \\
\hline 氖 & $\begin{array}{l}\text { Центральний банк Сгипту забезпечив } \\
\text { фінансування туризму на суму } 50 \\
\text { млрд. євро, знизивши процентну } \\
\text { ставку } 310 \% \text { до } 8 \% \text { (частина цих } \\
\text { коштів спрямовується на виплату } \\
\text { зарплати та на операційні витрати). В } \\
\text { межах вказаної ініціативи банки } \\
\text { можуть надавати кредитні засоби } 3 \\
\text { максимальним дворічним терміном } \\
\text { погашення. }\end{array}$ & $\begin{array}{l}\text { Скасовано податок на нерухомість } \\
\text { для готелів та туристичних } \\
\text { закладів терміном на шість } \\
\text { місяців; сплата всіх зборів для } \\
\text { підприємств індустрії гостинності } \\
\text { відтерміновується на три місяці; } \\
\text { всі базари та кафетерії, } \\
\text { розташовані в } \text { археологічних } \\
\text { пам’ятках, звільнено від сплати } \\
\text { орендної плати до безпечного } \\
\text { відновлення } \\
\text { запропоновано ту шестимісячний } \\
\text { план відстрочки комунальних } \\
\text { платежів (на електроенергію, воду } \\
\text { та газ) для туристичних закладів } \\
\text { та приватних авіакомпаній. }\end{array}$ \\
\hline
\end{tabular}


Продовження табл.1

\begin{tabular}{|c|c|c|}
\hline & $\begin{array}{l}\text { Агентство розвитку малого та } \\
\text { середнього бізнесу Enterprise Georgia } \\
\text { запустило механізм фінансової } \\
\text { підтримки, який } \\
\text { співфінансування процентних ставок } \\
\text { банківських позик для пансіонатів, } \\
\text { малих та середніх готелів (до } 50 \\
\text { номерів) на шестимісячний період. } \\
\text { Додаткові інвестиції спрямовуються в } \\
\text { туристичну інфраструктуру. Банки } \\
\text { реструктурують позики для всіх } \\
\text { фізичних осіб-підприємців, особливо } \\
\text { для тих, що працюють в туристичній } \\
\text { галузі. }\end{array}$ & \begin{tabular}{lcr} 
Підприємства, & \multicolumn{2}{c}{ діяльність яких } \\
пов’язана & з & туризмом, \\
звільняються & від податків на \\
майно та & прибуток. \\
Відтерміновується сплата податків \\
на власність та прибуток для \\
підприємств \\
сектору; туристичного \\
відшкодування ПдВ; збільшується \\
обсяг капітальних витрат, \\
закладених у бюджеті.
\end{tabular} \\
\hline & $\begin{array}{l}\text { Уряд надає } 600 \text { млрд. форинтів } \\
\text { підтримки на три роки через } \\
\text { інвестиційні субсидії, зменшення } \\
\text { податків для розвитку інфраструктури, } \\
\text { пільгові та гарантовані кредити та } \\
\text { капітальні програми. Пролонговано } \\
\text { короткострокові кредити для бізнесу. }\end{array}$ & $\begin{array}{l}\text { Роботодавці, які працюють у } \\
\text { постраждалих секторах економіки, } \\
\text { тимчасово звільняються від сплати } \\
\text { податку на заробітну плату, за } \\
\text { винятком внеску на охорону } \\
\text { здоров'я. }\end{array}$ \\
\hline 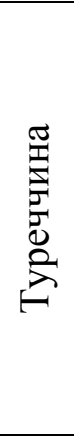 & $\begin{array}{l}\text { Вдвічі збільшено ліміт Фонду } \\
\text { гарантування кредитів (з } 25 \text { млрд TL } \\
\text { до } 50 \text { млрд TL) для малих та середніх } \\
\text { підприємств і компаній, які мають } \\
\text { дефіцит ліквідних активів та застави. } \\
\text { Виплату кредитних платежів } \\
\text { суб’єктами господарювання, які мають } \\
\text { фінансові проблеми через коронавірус, } \\
\text { відкладено на три місяці. }\end{array}$ & 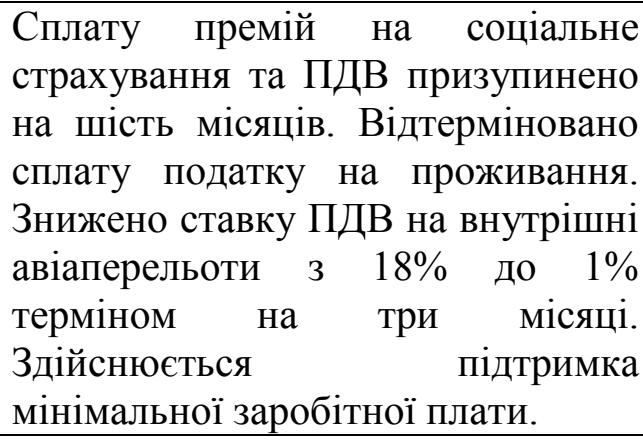 \\
\hline
\end{tabular}

*Джерело: сформовано за [13, с. 17-29]

Оскільки головним елементом у системі безпеки туризму $є$ власне безпека туриста, тому важливим завданням для суб'єктів туристичного сектору є забезпечення йому безпечних умов туристичної подорожі. Основними факторами, які негативно впливають на рішення споживачів туристичних послуг $є$ : обмеження на поїздки та закриття кордонів, що діють у більшості пунктів призначення; проблеми безпеки, пов'язані з поїздками; спалахи вірусу і відповідно ризики нових заборон; небезпека пов'язана з відсутністю надійної інформації; погіршення економічної ситуації [14, с. 67].

Дотримання вимог безпеки в умовах пандемії COVID-19 - одна 3 найважливіших умов відновлення туристичної сфери. Нині на забезпечення безпеки подорожуючих та працівників індустрії гостинності спрямована вимога реалізації спеціальних медичних протоколів для туристичного бізнесу. Ці протоколи передбачають такі стандартні заходи профілактики, як: соціальна дистанція; обов'язкове носіння захисних масок і дотримання заходів гігієни; регулярна санітарна обробка в місцях загального користування та в туристичному транспорті; щоденний контроль за самопочуттям персоналу і туристів. 3 липня 2021 р. для регулювання міжнародних туристичних потоків та забезпечення безпеки в усіх країнах ЄС і Шенгенської зони введено в дію 
електронні COVID-сертифікати, які дозволяють туристам підтверджувати на кордоні факт вакцинації, негативний результат ПЦР-тестування або факт одужання від коронавірусної інфекції.

Впровадження конкретних заходів щодо відновлення сфери туризму має особливе значення для країн, у яких цей сектор відіграє значну роль у національній економіці. Зокрема, Туреччина одна 3 перших країн запровадила програму Safe Tourism для підтримки туристичної галузі в умовах пандемії COVID-19. Програма сертифікації Safe Tourism визначає й рекомендує значний перелік заходів, які впроваджуються для безпечного перевезення, розміщення, перебування та контролю стану здоров'я як турецьких громадян, так і іноземних туристів, гостей і співробітників, які працюють на туристичних об'єктах.

Всі об’єкти програми Safe Tourism розділені на сім основних категорій (рис. 4), які оцінюються відповідно до міжнародних стандартів. Процес сертифікації туристичних об'єктів здійснюється міжнародною аудиторською компанією, уповноваженою профільним міністерством. 3 січня 2021 року для об'єктів розміщення, які мають номерний фонд не менше 30 номерів, наявність сертифікату безпеки на період їх експлуатації $\epsilon$ обов'язковою. Список об'єктів, які пройшли перевірку оприлюднюється на сайті Міністерства культури і туризму Туреччини. Логотип Сертифікації безпечного туризму розміщується на видимих ділянках перевіреного об’єкта. На всіх логотипах є QR-коди, через які гості і клієнти мають доступ до даних проінспектованого об'єкта [15].

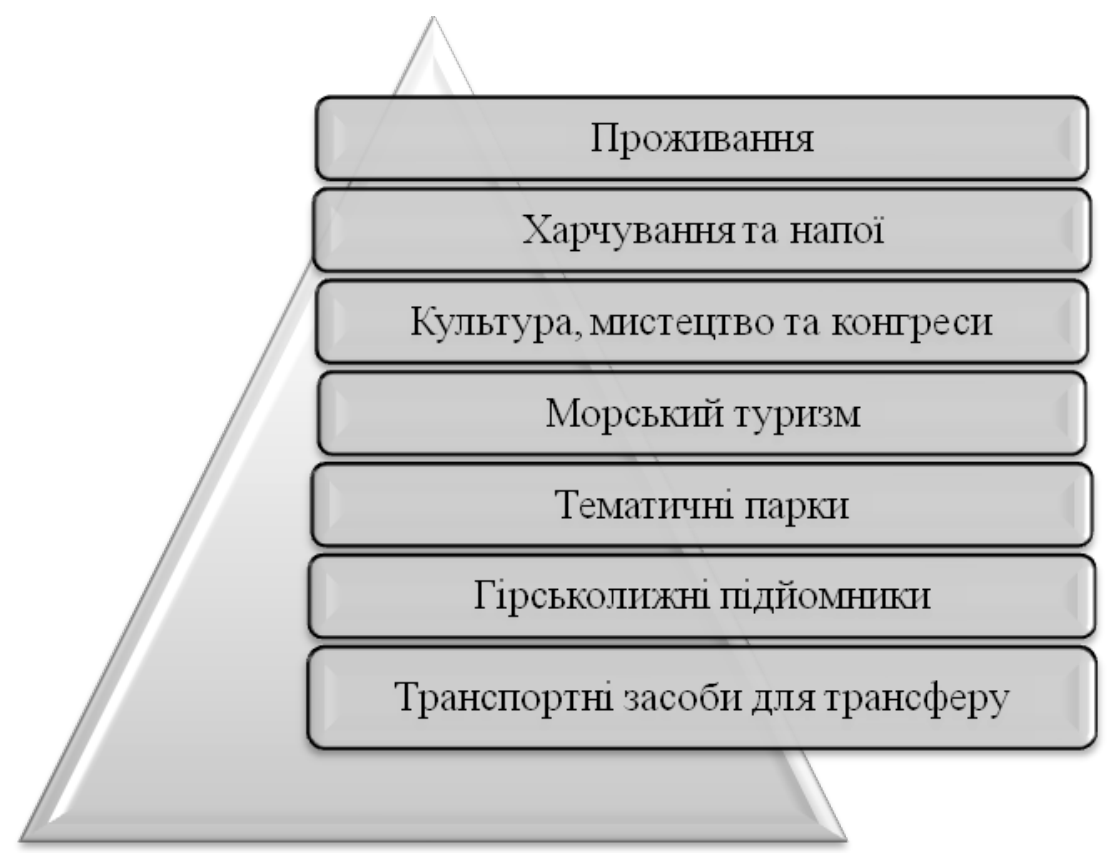

Puc. 4. Категорії об’єктів програми Safe Tourism*

Fig.4. Categories of objects of the program Safe Tourism

*Джерело: розроблено авторами за даними [15].

Обов'язковим для громадян та туристів, які прибувають у Туреччину є отримання HES-коду (Life Fits Into Home) - персонального коду, введеного Міністерством охорони здоров'я Туреччини для відстеження переміщення інфікованих COVID-19 або контактних 3 ними осіб (рис. 5). HES-код слугує виключно засобом зниження ризику зараження і потрібен майже в усіх державних установах, лікарнях, банках, магазинах, 
поштових відділеннях та під час користування муніципальним міським транспортом. Особи, які не інфіковані та не контактували з хворими на коронавірусну хворобу, отримують зелений HES-код, який дає їм право вільного пересування, інфікованим особам видається червоний HES-код, який зобов'язує їх до обов'язкової ізоляції.

Туреччині в результаті запровадження програми Safe Tourism вдалося збільшити туристичні потоки в країну. Згідно 3 даними Міністерства культури і туризму Туреччини, в січні-серпні 2021 р. кількість іноземців, які відвідали країну становила 14,1 млн осіб, що на 93,9\% більше порівняно з аналогічним періодом попереднього року. Водночас в другому кварталі 2021 р. держава отримала дохід від туризму обсягом понад 3 млрд доларів США (без урахування витрат на роумінг мобільного зв'язку та послуги пристаней) [16]. При цьому 73,1\% доходів від туризму отримано від іноземних туристів, а 26,9\% від громадян турецького походження, що проживають за кордоном.

Значна роль у запобіганні та мінімізації негативних наслідків ризиків, що супроводжують туристичну активність громадян, та ризиків суб'єктів туристичної діяльності відводиться страховим механізмам [17, с. 68]. Нині страховики в усьому світі відчули серйозний попит на страховий захист від COVID-19. Усвідомлення учасниками туристичного ринку необхідності убезпечення від ймовірних втрат через непередбачувані наслідки, що викликані коронавірусом, спонукає їх до подальшого збільшення витрат на страховий захист своїх майнових інтересів [18, с. 64].
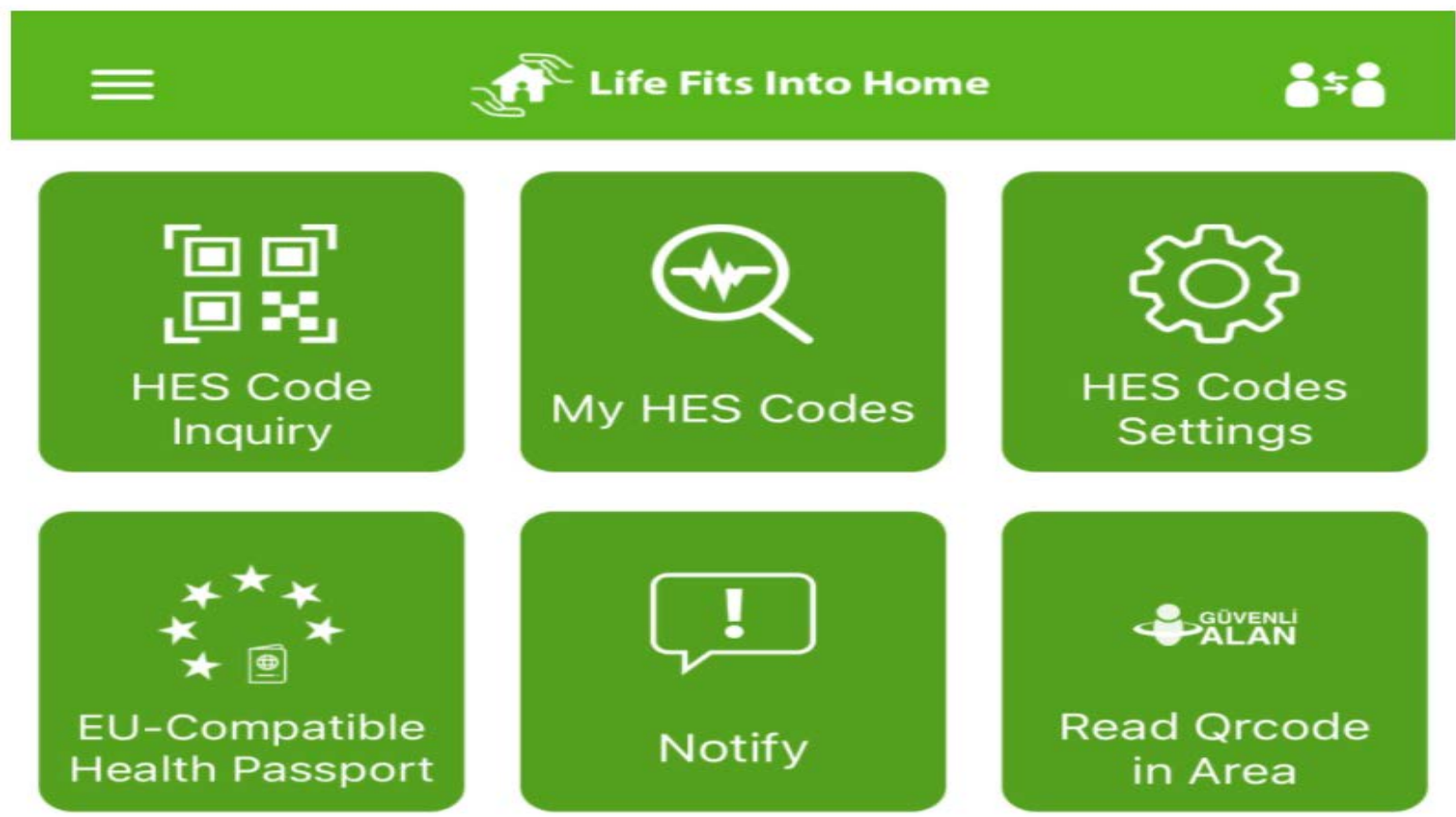

Рuc. 5. Мобільний додаток «Life Fits Into Home»*

*Джерело: [15].

Fig. 5. Mobile application «Life Fits Into Home»

Висновки. Безпека туризму це динамічний стан захищеності сфери туризму від внутрішніх і зовнішніх загроз, що дає змогу забезпечити ії надійне існування і стійкий розвиток Пандемія COVID-19 негативно вплинула на розвиток туристичної галузі й створила відповідні загрози для іiї ефективного функціонування. Для виходу з кризової ситуації та відновлення туристичної активності перед урядами країн першочерговим постає завдання адаптації до нових реалій та розроблення комплексу ефективних заходів, спрямованих на підтримку туристичної галузі та мінімізацію наслідків карантинних обмежень. Ефективна економічна безпека індустрії туризму можлива 
лише за умови забезпечення комплексного і системного підходу до іiі організації. Важливим чинником відновлення туристичної сфери $є$ досягнення оптимального балансу між питаннями безпеки, охорони здоров'я та економічними інтересами. Обов'язковою передумовою відновлення довіри учасників туристичного ринку $є$ безпечність поїздок, узгодження протоколів безпеки та ефективні комунікації. Для подальшого убезпечення туристичної галузі від ризиків негативного впливу пандемії COVID-19 важливо вивчати передовий досвід країн світу щодо їх подолання та розробляти нові механізми для їі ефективного функціонування в майбутньому.

1. International tourism and COVID-19. UNWTO. URL: https://www.unwto.org/international-tourism-andcovid-19 (дата звернення: 01.10.2021р.).

2. UNWTO World Tourism Barometer and Statistical Annex, July 2021. UNWTO. URL: https://www.eunwto.org/doi/abs/10.18111/wtobarometereng.2021.19.1.4 (дата звернення: 01.10.2021р.).

3. Голод А. П. Безпека регіональних туристичних систем: теорія, методологія та проблеми гарантування : монографія. Львів : ЛДУФК, 2017. 350 с.

4. Денисов О. С. Теоретичний дискурс сутності та становлення вчення про економічну безпеку галузі у відкритій економіці. Інтелект ХХІ. 2017. № 4. С. 9-13.

5. Бобкова А. Г., Кудреватых С. А., Писаревский Е. Л. Безопасность туризма. Москва : Федеральное агентство по туризму, 2014. $272 \mathrm{c.}$

6. Захаров О. І., Снігир А. В. Аналіз загроз економічній безпеці туристичних підприємств. Науковий вісник Львівського державного університету внутрішніх справ. Серія економічна. 2014. Вип. 2. С. 297-305.

7. Забаштанський М. М., Забаштанська Т. В., Роговий А. В. Економічна безпека держави в умовах трансформаційних змін туристичної галузі України. Проблеми системного підходу в економіці. 2019. Вип. 4(1). С. 50-55. DOI: https://doi.org/10.32782/2520-2200/2019-4-7.

8. Про туризм : Закон України від 15.09.1995 р. № 324/95-BP. Верховна Рада Украӥни. URL: https://zakon.rada.gov.ua/laws/show/324/95-вр\#Техt (дата звернення: 14.10.2021р.).

9. Лазарева А. П. Особливості економічної безпеки підприємств туристичної сфери. Теоретичні $i$ практичні аспекти економіки та інтелектуальної власності. 2014. Вип. 1, Т. 2. С. 271-276.

10. UNWTO Launches a call for action for tourism's COVID-19 mitigation and recovery. UNWTO. URL: https://www.unwto.org/news/unwto-launches-a-call-for-action-for-tourisms-covid-19-mitigation-andrecovery (дата звернення: 02.10.2021р.).

11. UNWTO Launches Comprehensive Tourism Recovery Tracker. UNWTO. URL: https://www.unwto.org/news/unwto-launches-comprehensive-tourism-recovery-tracker (дата звернення: 02.10.2021 p.).

12. Пандемія COVID-19 та іï наслідки у сфері туризму в Україні. (Оновлення до документа «Дорожня карта конкурентоспроможного розвитку сфери туризму в Україні»). URL: https://ntoukraine.org (дата звернення: 10.10.2021 р.).

13. Жаліло Я. А., Ковалівська С. В., Филипенко А. О., Химинець В. В., Головка А. А. Щодо розвитку туризму в Україні в умовах підвищених епідемічних ризиків: Аналітична записка Національного інституту стратегічних досліджень. Київ, 2019. 29 с.

14. Кирилюк I. Розвиток туризму в умовах пандемії COVID-19. Туризм у XXI столітті: виклики та реагування [Матеріали міжнародної науково-практичної конференції]. Київ, 2020. С. 67-69.

15. Safe Tourism. Go Türkiye. URL: https://safetourismturkiye.com/ru/homepage (дата звернення: 14.10.2021 p.).

16. Turizm İstatistikleri, II. Çeyrek: Nisan - Haziran, 2021. Türkiye Cumhuriyeti Kültür ve Turizm Bakanlı̆̆ı. URL: https://data.tuik.gov.tr/Bulten/Index?p=Turizm-Istatistikleri-II.-Ceyrek:-Nisan---Haziran,-202137441 (дата звернення: 15.10.2021р.).

17. Чвертко Л. А., Демченко Т. А. Страхування туристичних ризиків: проблеми теорії та практики. Економічні горизонти. 2018. № 1(4). С. 67-75.

18. Чвертко Л. А., Вінницька О. А., Корнієнко Т. О. Стан та проблеми розвитку туристичного страхування в Україні. Актуальні проблеми розвитку економіки регіону. 2020. Вип.16. Т.1. С. 5867. DOI: 10.15330/apred.1.16.58-67.

References

1. «International tourism and COVID-19». UNWTO, www.unwto.org/international-tourism-and-covid-19. Accessed 01 Oct. 2021.

2. «UNWTO World Tourism Barometer and Statistical Annex, July 2021». UNWTO, www.eunwto.org/doi/abs/10.18111/wtobarometereng.2021.19.1.4. Accessed 01 Oct. 2021. 
3. Holod, A. P. Safety and security of regional tourism systems: theory, methodology and problems of guarantee, LDUFK, 2017.

4. Denysov, O. Ye. «Theoretical discourse of the entity and the doctrine of economic security in the open economy». The Informer XXI, no. 4, 2017, pp. 9-13.

5. Вовкоva, A. G., Kudrevatykh, S. A., and Ye. L. Pisarevskiy. Safety of tourism, Federal Agency for Tourism, 2014.

6. Zakharov, O. I. and A. V. Snigir «The analysis of the economic security threats of tourism enterprises». Scientific Bulletin of Lviv State University of Internal Affairs. The series is economic, issue 2, 2014, pp. 297-305.

7. Zabashtanskyi, M. M., Zabashtanska, T. V. and A. V. Rogovyi. «Economic security of the state in conditions of the transformation changes of the tourist industry of Ukraine». Problems of Systemic Approach in the Economy, issue 4(1), 2019, pp. 50-55. DOI: https://doi.org/10.32782/2520-2200/2019-47.

8. On tourism: Law of Ukraine of 15.09.1995 № 324/95-VR. Verkhovna Rada of Ukraine. Verkhovna Rada of Ukraine, zakon.rada.gov.ua/laws/show/324/95-вp\#Text. Accessed 14 Oct. 2021.

9. Lazareva, A. P. «Features of economic security of enterprises of tourist sphere». Theoretical and Practical Aspects of Economics and Intellectual Property, issue 1, vol. 2, 2014, pp. 271-276.

10. «UNWTO Launches a call for action for tourism's COVID-19 mitigation and recovery». UNWTO, www.unwto.org/news/unwto-launches-a-call-for-action-for-tourisms-covid-19-mitigation-and-recovery. Accessed 02 Oct. 2021.

11. «UNWTO Launches Comprehensive Tourism Recovery Tracker». UNWTO, www.unwto.org/news/unwto-launches-comprehensive-tourism-recovery-tracker. Accessed 02 Oct. 2021.

12. COVID-19 pandemic and its consequences in the field of tourism in Ukraine (Update to the document «Roadmap for competitive development of tourism in Ukraine»), ntoukraine.org. Accessed 10 Oct. 2021.

13. Zhalilo, Ya. A., Kovalivska, S. V., Fylypenko, A. O., Khymynets, V. V., and A. A. Golovka. Regarding the development of tourism in Ukraine in the conditions of increased epidemic risks: Analytical note of the National Institute for Strategic Studies, 2019.

14. Kyryliuk, I. «Development of tourism in the conditions of the COWID-19 pandemic». Tourism in the 21st Century: Challenges and Responses, 2020, pp. 67-69.

15. Safe Tourism. Go Turkey, safetourismturkiye.com/ru/homepage. Accessed 14 Oct. 2021.

16. «Tourism Statistics, II. Quarter: April - June, 2021». Republic of Turkey Ministry of Culture and Tourism, data.tuik.gov.tr/Bulten/Index?p=Turizm-Istatistikleri-II.-Ceyrek:-Nisan---Haziran,-2021-37441. Accessed 15 Oct. 2021.

17. Chvertko, L. A., and T. A. Demchenko. «Insurance of tourist risks: problems of theory and practice». Economic horizons, no. 1 (4), 2018, pp. 67-75.

18. Chvertko, L. A., Vinnytska, O. A., and T. O. Korniienko. «State and problems of tourist insurance development in Ukraine». The actual problems of regional economy development, issue 16, vol. 1. 2020, pp. 58-67. Doi: 10.15330/apred.1.16.58-67.

УДК 332.1:338

doi: 10.15330/apred.2.17.189-195

Шекета С.Ю. ${ }^{1}$, Казюка Н.П. ${ }^{2}$

\title{
ЕФЕКТИВНИЙ МЕНЕДЖМЕНТ СФЕРИ ТУРИЗМУ ЯК ЗАПОРУКА СТАЛОГО ЕКОНОМІЧНОГО РОЗВИТКУ ОБ'СДНАНИХ ТЕРИТОРІАЛЬНИХ ГРОМАД ПРИКАРПАТТЯ
}

\author{
${ }^{1}$ Івано-Франківський коледж \\ Львівського національного аграрного університету, \\ вул.Юності, 11, м. Івано-Франківськ, \\ 76492, Україна, \\ тел.: 0342554722, \\ e-mail: sheketa-evgenija@ukr.net, \\ ORCID: 0000-0001-7182-9447
}

